\title{
Characteristics, distribution and diagenetic stages of chert in the La Silla Formation (Lower Ordovician), Argentine Precordillera
}

\author{
MARIANA M. RAVIOLO ${ }^{1}$, JOSÉ A. BARBOSA ${ }^{2}$ and VIRGÍNIO H. NEUMANN ${ }^{2}$ \\ ${ }^{1}$ CONICET-CCT-IANIGLA, Av. Ruiz Leal s/n, Parque General San Martin, CC 330, 5500, Mendoza, Argentina \\ ${ }^{2}$ LAGESE-DGEO, Centro de Tecnologia e Geociências, Universidade Federal de Pernambuco \\ Rua Acadêmico Hélio Ramos s/n, Cidade Universitária, 50740-530 Recife, PE, Brasil \\ Manuscript received on September 19, 2007; accepted for publication on June 17, 2009; \\ presented by ALCIDES N. SIAL
}

\begin{abstract}
The late Cambrian - late Tremadocian La Silla Formation is a carbonate unit of the eastern Precordillera in Argentina whose facies indicate a shallow platform environment. Until this moment, there were no studies that referred to the diagenetic evolution of these rocks. The present study involves the characteristics and distribution of the silicification that affects this unit and determines its different diagenetic stages through petrographic (with cathodoluminescence support) and stratigraphic analyses. An early diagenetic chert, in a stage previous to the compactation, was observed. This chert is related to silica-rich seawater in contact with permeable and porous sediments. A later pulse of chert, associated with fracturing, also occurs. The knowledge provided by the characteristics and distribution of chert in these carbonates is significant, especially when considering that the La Silla Formation in San Juan province is the most quarried unit for the elaboration of lime.
\end{abstract}

Key words: carbonates, chert, early diagenesis, eastern Precordillera, Lower Ordovician.

\section{INTRODUCTION}

Chert is a hard, dense or compact sedimentary rock, consisting of micro- or cryptocrystalline quartz crystals that contain amorphous silica (opal) and impurities such as calcite or iron oxide (Bates and Jackson 1980). There are many references to chert associations in carbonates; comprising different depositional environments and ages (Geeslin and Chafetz 1982, Maliva and Siever 1989, Gao and Land 1991, Lawrence 1994, Giménez-Montsant et al. 1999, Pope 2004). Chert can provide a window to the original composition of the sediment, the diagenetic history and the biota of the host rock due to its low susceptibility to further diagenetic alterations (Maliva 2001).

Correspondence to: Mariana M. Raviolo

E-mail: mraviolo@lab.cricyt.edu.ar
The La Silla Formation (Keller et al. 1994) of late Cambrian to late Tremadocian age, is a carbonate unit of the eastern Precordillera whose facies indicate a shallow platform environment (Cañas 1999, Keller 1999, M.M. Raviolo et al., unpublished data). It is free of terrigenous material and is extensively quarried to produce lime. The present study was carried out in the southern outcrops of the La Silla Formation in the Cerro Pedernal, Cerro Pedernal de los Berros, Loma Redonda, Sierra Chica de Zonda, and Sierra de Villicum (Fig. 1).

Among the different studies involving this Formation, only the abundance of chert present in this unit and its importance as a rock-constituting element were mentioned (Cañas 1999, Keller 1999); in recent carbon isotopic studies (Buggisch et al. 2003, Sial et al. 2008) it also mentions the importance of this component and the way its presence affects the interpretation of the obtained data. Nevertheless, there are no references con- 


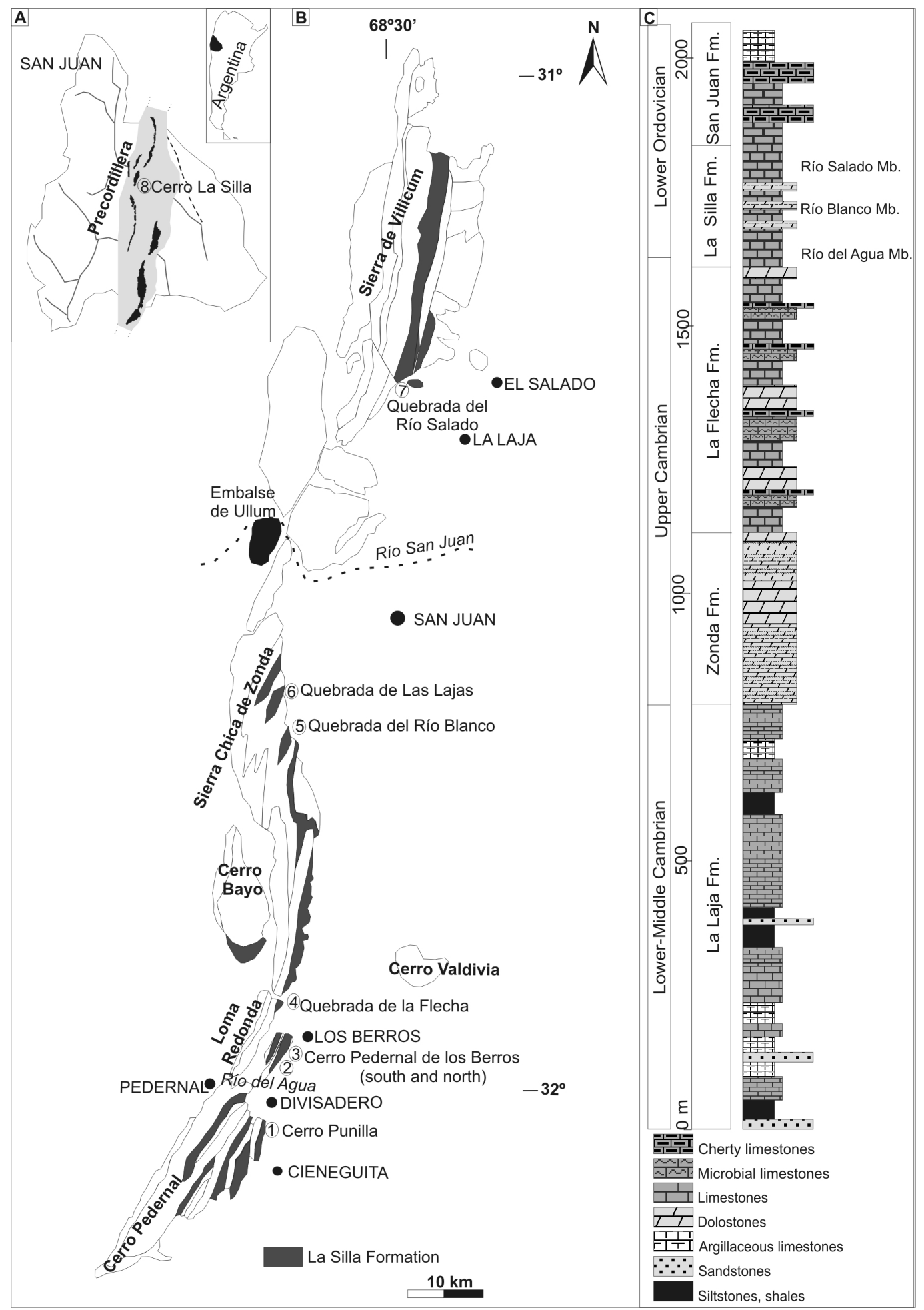

Fig. 1 - Study area in western Argentina. A - Map of the province of San Juan showing the location of the Precordillera terrane and the type section of the La Silla Formation (8). B - Map of the eastern Precordillera in the vicinity of San Juan showing the distribution of the La Silla Formation in its southern sector, and the location of the measured sections (1-8). C - Cambro-Ordovician stratigraphy of the Precordillera in the vicinity of San Juan. 
cerning the type of chert, its location, characteristics and diagenetic history in this area known for heavy explotation that require high quality for its industrial use.

The aim of this study is to recognize, describe and locate in the stratigraphic columns of the La Silla Formation the different types of chert and to establish the different pulses that provided silicification, related to the depositional environment in early stages.

\section{LOCATION AND GEOLOGY OF THE AREA UNDER STUDY}

The Argentine Precordillera is a geological unit located in the central-western part of Argentina, and is distributed among Mendoza, San Juan and La Rioja provinces. It is bordered to the west by the Cordillera Frontal and to the east by the western Sierras Pampeanas. Precordillera was subdivided into three separate belts according to its respective sedimentary successions and structural style: Precordillera Oriental (Ortiz and Zambrano 1981), Occidental, and Central (Baldis and Chebli 1969) (i.e. eastern, western, and central Precordillera).

The Precordillera Oriental, located in San Juan Province, has a regional structure composed of imbricated thrust sheets with westward vergence, elevated as stacked thrust sheets dipping to the east (e.g. Ramos 1988, 1999, Alvárez-Marrón et al. 2006). This study has been carried out in the southern sector of Precordillera Oriental. The southern sector is located at $31^{\circ} \mathrm{S}-32^{\circ} \mathrm{S}$ and along $68^{\circ} 30^{\prime} \mathrm{W}$ near the city of San Juan, including the Cerro Pedernal, Cerro Pedernal de Los Berros, Sierra Chica de Zonda and Sierra de Villicum (Fig. 1).

\section{STRATIGRAPHY}

The core of the Precordillera Oriental and Central is a $2000 \mathrm{~m}$ thick carbonate succession that was accumulated in a wide shallow platform developed during the late Early Cambrian through Middle Ordovician. The Cambro-Ordovician platform succession of the Precordillera Oriental consists of five formations (Fig. 1), from base to top: La Laja, Zonda, La Flecha, La Silla and San Juan (Keller 1999, Bordonaro 2003a, b).

The La Silla Formation was established by Keller et al. (1994) in order to describe thick-bedded, lightcoloured limestones that had previously comprised the lower part of the San Juan Formation (Kobayashi 1937). The type section was defined at Cerro La Silla, southeast of Jáchal (north of San Juan Province), reaching up to $360 \mathrm{~m}$ in thickness. For the southern sector, Raviolo et al. (2007) established a three-fold subdivision based on the presence of dolostone beds, from base to top: Río del Agua, Río Blanco and Río Salado members, respectively $85 \mathrm{~m}, 140 \mathrm{~m}$ and $81 \mathrm{~m}$ thick in their type sections. The interbedding of dolostone (generally with chert nodules and lenses) and limestone distinguishes the Río Blanco Member from the lower and upper members that are mainly massive limestones (Fig. 2).

\section{FACIES OF THE LA SILla ForMATION}

Here, the array of carbonate rock types is grouped into eight recurring facies. The facies are described below in order of their decreasing relative abundance that is consistent in all measured sections; peloidal grainstone is by far the most common facies, giving the La Silla Formation a monotonous appearance (Fig. 2).

\section{Facies 1: Peloidal grainstone}

This facies is composed of generally well-sorted peloids with a variable amount of admixed lumps; scattered abraded bioclasts and rare ooids and grapestones are also present. Local packstone textures rarely occur. Bedding is thick to massive and mostly tabular; many basal contacts are sharp. Grading is absent. Bioturbation is locally common and some burrows are attributable to Thalassinoides. Unidirectional cross-lamination from ripples and small dunes occur locally. In places, especially in the Río Blanco Member, beds of Facies 1 are replaced by massive, light, buff-coloured, crystalline dolomite. This is generally associated with black chert nodules and beds.

This facies represents deposition under more or less uniformly elevated energy, probably as shifting and accreting sand sheets and rarely as low-relief bars.

\section{Facies 2: Laminated dolostone}

Whitish, finely crystalline dolostone is locally intercalated with non-dolomitized Facies 1 and forms thin to medium beds that are tabular to lenticular at meter scale. They may exhibit planar-lamination or cross-lamination indicating waves or uni-directional currents; wave-ripples are common at bed tops. This facies occurs either 


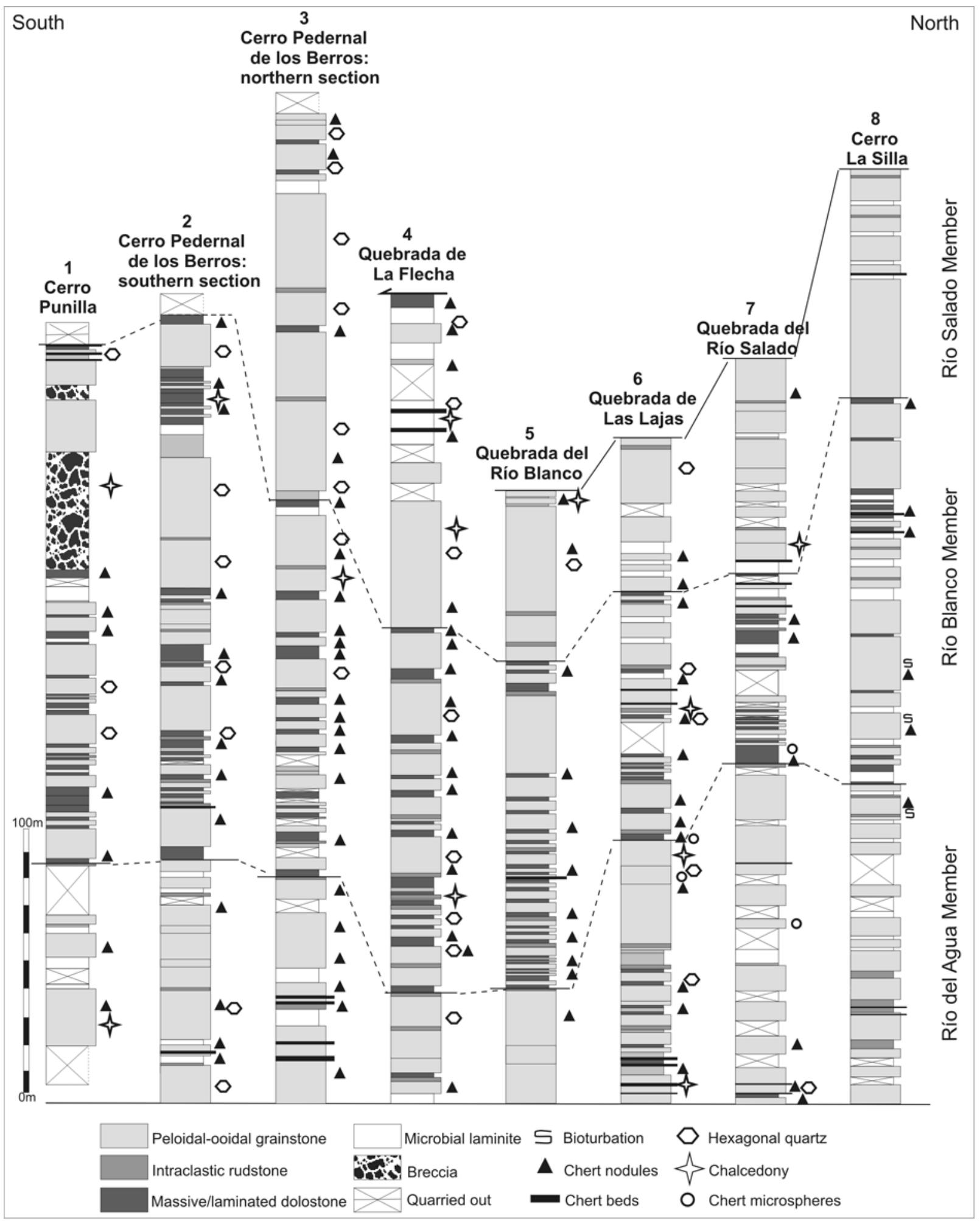

Fig. 2 - Lithological logs of the eight measured sections showing approximate distribution of lithofacies. The base is the contact between La Flecha and La Silla Formations (inferred at locality 1 where it is not exposed). The contact with the overlying San Juan Formation is correlated between localities 5 to 8 where it is exposed. Different types of chert are represented by symbols. 
as individual beds with sharp, erosive bases, or gradationally as overlying intraclastic rudstone (Facies 3 ) that has cut into Facies 1.

The lamination is wave- or current-induced rather than microbial, and is more likely to indicate sporadic events of significantly higher energy than background conditions.

\section{Facies 3: Intraclastic rudstone}

This flat-pebble conglomerate facies consists of subangular to rounded intraclasts composed of lime mudstone and/or grainstone-packstone, with a matrix of peloidal or ooidal grainstone and locally containing thin lime mudstone intercalations. Intraclasts are horizontal to gently imbricated. In some beds, the intraclasts are preferentially dolomitized. They form thin beds and meter-scale lenses about $10-50 \mathrm{~cm}$ thick.

This is the coarsest facies in the La Silla Formation, which is believed to have been formed by major erosive events after a period of relative quiescence, leading to cementation of some of the underlying sediments.

\section{Facies 4: Microbial laminite}

This facies consists of parallel planar to wavy laminae, sometimes doming to low-relief, laterally-linked hemispheroidal (LLH) stromatolites, forming beds a few centimetres thick and at least $1 \mathrm{~m}$ in lateral extent. In a single bed in Cerro La Silla, relief is up to $20 \mathrm{~cm}$. Laminae are composed of millimetre-scale alternations of dolostone and mudstone or mudstone and peloidal grainstone. Locally laminae are accentuated by preferential silicification. No fossils are present.

The lack of associated high-energy sedimentary structures, the uniformity and laterally extensive planar lamination and occasionally developed fenestral fabrics are evidence of microbial accretion under protected, low-energy conditions.

\section{Facies 5: Peloidal packstone}

This facies is scarce and is generally thick-bedded, although locally it can be thin-bedded or somewhat nodular. It commonly possesses a mottling due to moderate bioturbation by Thalassinoides burrows that may be enhanced by preferential dolomitization or silicification. It also occurs as a matrix in thrombolite patch reefs.
The peloidal nature of the framework grains shows that this sediment was originally deposited under somewhat turbulent submerged conditions as Facies 1, but was modified by extensive bioturbation under lower energy conditions.

\section{Facies 6: Ooidal grainstone}

This facies is composed of locally cross-laminated, wellsorted ooids with variably admixed grapestones, plus scarce peloids and bioclasts. This facies ranges from thin-bedded to massive, generally tabular beds.

Like Facies 1, the ooidal facies was originated under persistent but relatively gentle turbulence that led to sand flats and low-relief shoals.

\section{Facies 7: Thrombolite boundstone}

Thrombolite patch reefs are less than $0.5 \mathrm{~m}$ in diameter and thickness. They consist of thromboids flanked by unburrowed to sporadically burrowed, peloidal grainstonepackstone, commonly with trilobite sclerites. Generally, they display a radial-columnar fabric that imparts a mottled aspect due to contrasting texture and colour between the internal thromboids and matrix that in some places is picked out by preferential dolomitization. These are patch-reef boundstones formed in a shallow environment of moderate and intermittent turbulence.

\section{Facies 8: Mudstone}

Lime mudstones and peloidal or bioclastic wackestones are very scarce as well. They form laminae intercalated with Facies 1 and Facies 3. Thus, they are too small to be portrayed in Figure 2.

The rarity of mudstone over the large portion of the platform studied indicates that very little lime mud was generated. The mud laminae observed within coarser facies point to brief spells of quiet conditions and fallout from suspension.

\section{MATERIALS AND METHODS}

This study is based on eight detailed sections: Cerro Punilla, Cerro Pedernal de los Berros, Quebrada de La Flecha, Quebrada del Río Blanco, Quebrada de Las Lajas, Quebrada del Río Salado, and Cerro La Silla. In each section sedimentary structures, carbonate grains, 
and especially the characteristics of silicification were identified and described. In order to perform specific analyses, a detailed sampling of the different lithologies recognized was obtained. Abundant thin sections (300) and polished sections (100) of rock samples were carried out in the laboratory of Petrology of the Universidad Nacional de San Juan (INGEO), Argentina. These sections were studied using a petrographic-calcographic microscope Olympus BH-2 with an Olympus digital camera.

Samples with interesting features related to silicification were chosen, and special thin sections (30) were made for cathodoluminescence $(\mathrm{CL})$ analysis. The $\mathrm{CL}$ equipment used consists of a petrographic microscope NIKON E600 ECLIPSES W POL, with a NIKON (model H-III) camera. Cathodoluminescence module for optic microscope is CLmk4 8200 of Cambridge Technology LTD, with a hot-cathode technique. The analyses were carried out in the Laboratory of Sedimentary Geology (LAGESE) on the CL Laboratory (LCT) of the Department of Geology, Federal University of Pernambuco (UFPE), Recife, Pernambuco, Brazil.

\section{CHERT CHARACTERISTICS}

On a regional scale, chert is very common; it is found in all the stratigraphic sections. Chert is more abundant in dolostones, but it is also found in limestones. Because most of the dolostone banks have chert, it is very important in the Río Blanco Member (see Figs. 2 and 3).

On a local scale (meters to centimetres), chert can be seen as: beds with planar base and top, up to $1 \mathrm{~m}$ thick, in agreement with a stratification that can be laterally followed by several meters (Fig. 3A). It has lenses about $10-50 \mathrm{~cm}$ thick (Fig. 3B, C), also with lateral extension; elipsoidal nodules of few centimetres; irregularly distributed mottles (Fig. 3D); and laminae. The colour ranges from white to black.

In a more detailed view, some of the chert types are associated to specific facies: nodules, for example, are more common in peloidal or ooidal grainstones; irregular mottles are connected with bioturbation, and laminae are associated with planar or stromatolitic microbial structures.

From a microscopic scale, chert can be described as: micro-quartz, which corresponds to equidimensional grains $<20 \mu \mathrm{m}$ in size (Fig. 4A, B; Fig. 5A; Fig. 6).
This quartz is so fine-grained that, when replace micritic grains (peloids, ooids), the shape of these grains is conserved; thus, they are called "ghosts"; megaquartz, grains $>20 \mu \mathrm{m}$ (Fig. 4C); and chalcedony, which develop radial fibers until $700 \mu \mathrm{m}$ (Fig. 4D). The megaquartz presents a varied range of colours from gray to orange; when the grain size increases towards the inner side of the pore, it gives a drusy texture. The contacts among these crystals are planar to sub-rounded. Chalcedony has a radial texture and variable coloration. Another feature observed in thin sections is authigenic quartz, hexagonal to pseudohexagonal, with calcite inclusions in the core of the crystal. The maximum size of these crystals is $250 \mu \mathrm{m}$ (Fig. 4E). In some cases, there are silica microspheres with radial extinction, $200 \mu \mathrm{m}$ of average diameter (Fig. 4F). Microscopic chert is randomly distributed in all facies, without a specific pattern.

\section{SILICIFICATION AND OTHER DIAGENETIC PROCESSES}

As previously mentioned, the association between chert and dolostones is very common; at a microscopic scale, some typical characteristics are: dolomite crystals that develop between the contact of chert and limestone; dolomite rhombs floating in a siliceous matrix, and dolomite laminae crossing chert nodules.

Another important relationship that could be clearly observed under the microscope is between silicification and compactation. In the same thin section, it is possible to observe different responses of the carbonate grains to compactation (Fig. 5). While in one sector of the thin section peloids and ooids are completely replaced by chert, keeping their original shape (Fig. 5A), in another sector unsilicified carbonate grains have experienced a high degree of deformation (Fig. 5B). The same response is observed in examples of non-silicified dolomites $v s$. silicified dolomites.

The connection between chert and fractures is also noted. It is possible to observe silicification pulses contemporaneous with fracturing. This is better described in Cathodoluminiscence section.

\section{CATHODOLUMINESCENCE}

The employment of this technique could confirm some observations carried out on an outcrop scale and through 

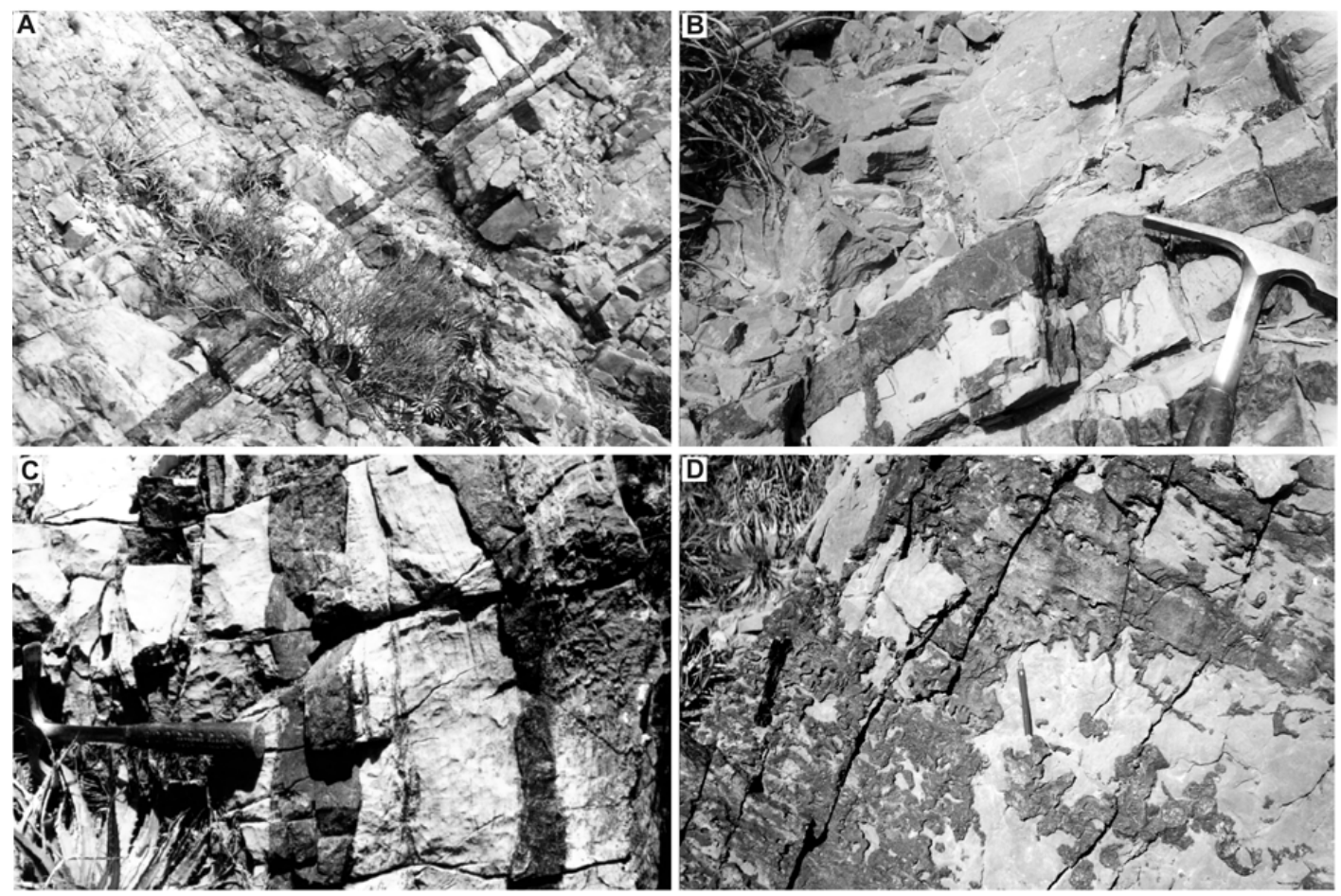

Fig. 3 - Chert in outcrop. A - Beds of black chert, Quebrada de Las Lajas. B - Lenses of chert, Quebrada del Río Salado. C - Beds of chert associated with a stromatolite (top to the left of the picture), Cerro Pedernal de Los Berros, northern section. D - Bioturbation replaced by chert, Cerro La Silla. All pictures correspond to examples in Río del Agua member, in dolostone banks.

petrographic microscope. In Figure 6A, carbonate grains $(\mathrm{OO})$ and the cement among them are totally replaced by micro-quartz (CQ) that gives a dark colour to the complete thin section. The fracture cuts diagonally, and it is filled by Mn calcite (bright colour); there is a later replacement of the quartz cement with calcite around the fracture; it is clearly observed in the rim of the ooids (arrow). Figure 6B shows the same thin section in a different sector; to the left of the picture, the non-luminiscent micro-quartz that rims the grains (OO) is more intense than to the right. The fracture is filled with Mn calcite containing a fragment of dark filling (arrow) that probably corresponds to a previous siliceous filling. Later pulses of Mn calcite are found replacing the micro-quartz (C). In this example, it is clear that silicification was intense and affects the entire rock components. It is possible to observe in Figure 6C the relationship between silicification and fracturation and their different stages. The oldest fractures seem to be those associated with almost vertical direction (A), with a siliceous filling (non-luminescent). There is another group of fractures almost perpendicular to A, indicated as B and C. They are also sealed by a dark filling, indicating that they were the first ones to be formed and the fluid composition at the moment were silica rich. Cutting $\mathrm{A}, \mathrm{B}$, and $\mathrm{C}$, a new group of horizontal fractures (D and E) is formed; the thickest one (D) is sealed by $\mathrm{Mn}$ rich calcite. This indicates that there was a change in the fluids that circulated through these new fractures; calcite was not precipitated in the first ones as they were sealed. It is observed that D was re-opened and filled by a dark Fe rich calcite (vertical arrows). There is a fourth stage of fractures: $F, G$ and $H$ that have similar orientation to $\mathrm{A}$. The $\mathrm{F}, \mathrm{G}$ and $\mathrm{H}$ cut $\mathrm{D}$ and $\mathrm{E}$ and are also sealed by calcite. There is a sector of F and A (thicker arrows) showing a non-luminescent filling, and another area with light colour (calcite) indicating probable reactivation of fractures. There are, at least, four fracturing phases. The first and the last phases agree in their orientation and indicate a reactivation stage. The fluid that circulated through the fractures suffered modifications: it was initially of siliceous composition, later of $\mathrm{Mn}$ 

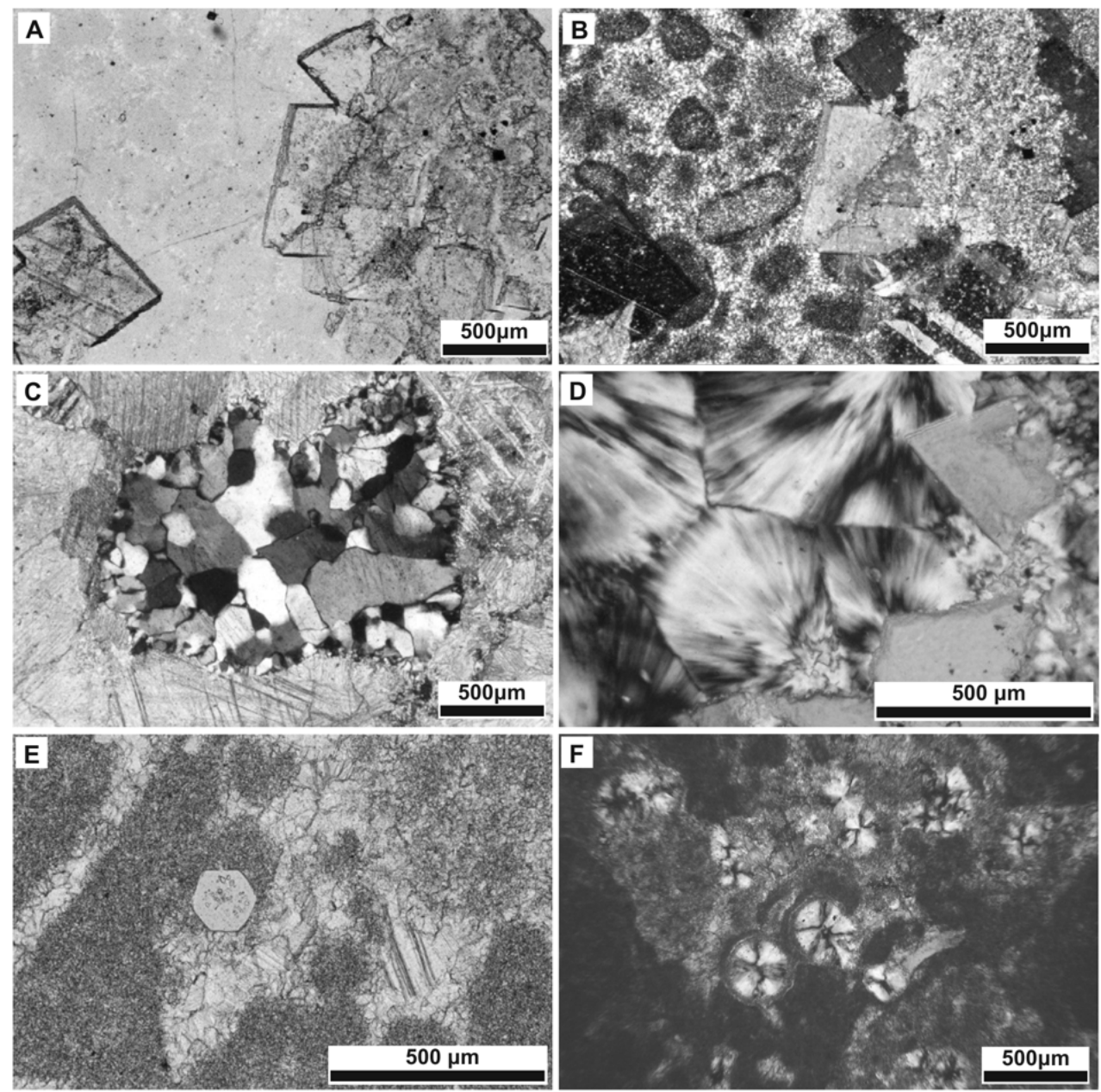

Fig. 4 - Different types of chert in thin section. A - Micro-quartz associated with well developed dolomitic rhombs. Plane-polarized light. B - Same section that A, crossed nicols. It is possible to see the carbonate grains (peloids) completely replaced by micro-quartz. C - Cavity occupied by mega-quartz, drusy texture. Crossed nicols. D - Fibrous chalcedony associated with dolomite. Crossed nicols. E-Autighenic hexagonal quartz. Crossed nicols. F - Silica microspheres. Crossed nicols.

rich calcite, and then possibly of dark Fe rich calcite. In Figure 6D there are other fractures in the same thin section as $6 \mathrm{C}$. The oldest one corresponds to $\mathrm{A}$ and show dark calcite and silica filling. Then, B cuts A and is $\mathrm{Mn}$ rich calcite (bright colour). After that, $\mathrm{C}$ cuts $\mathrm{B}$. Fractures $\mathrm{A}$ and $\mathrm{C}$ have a similar orientation. When $\mathrm{C}$ was generated, it became sealed by variable proportions of Mn calcite (light and dark areas). This also indicates that different stages of the crack-seal process in the fractures were accompanied by variations in the chemistry of the fluid that circulated through them, ranging from being $\mathrm{Mn}$ to $\mathrm{Fe}$ rich in its composition.

\section{DIAGENETIC INTERPRETATION}

The distribution of nodules, lenses, and beds of chert conformable with the stratification and mainly associated with grainstones facies can be related with the permeability of the original sediments that favoured the circulation of silica rich fluids in an early diagenetic stage (Gao and Land 1991). Silicification took place before the compactation that destroyed the trace fossils in the case of bioturbations replaced by chert (Pope 2004). Other examples are small cavities filled with chert, pointing to an earlier episode of silica precipitation, previous to the burial stage (Tobin 2004). In the case 


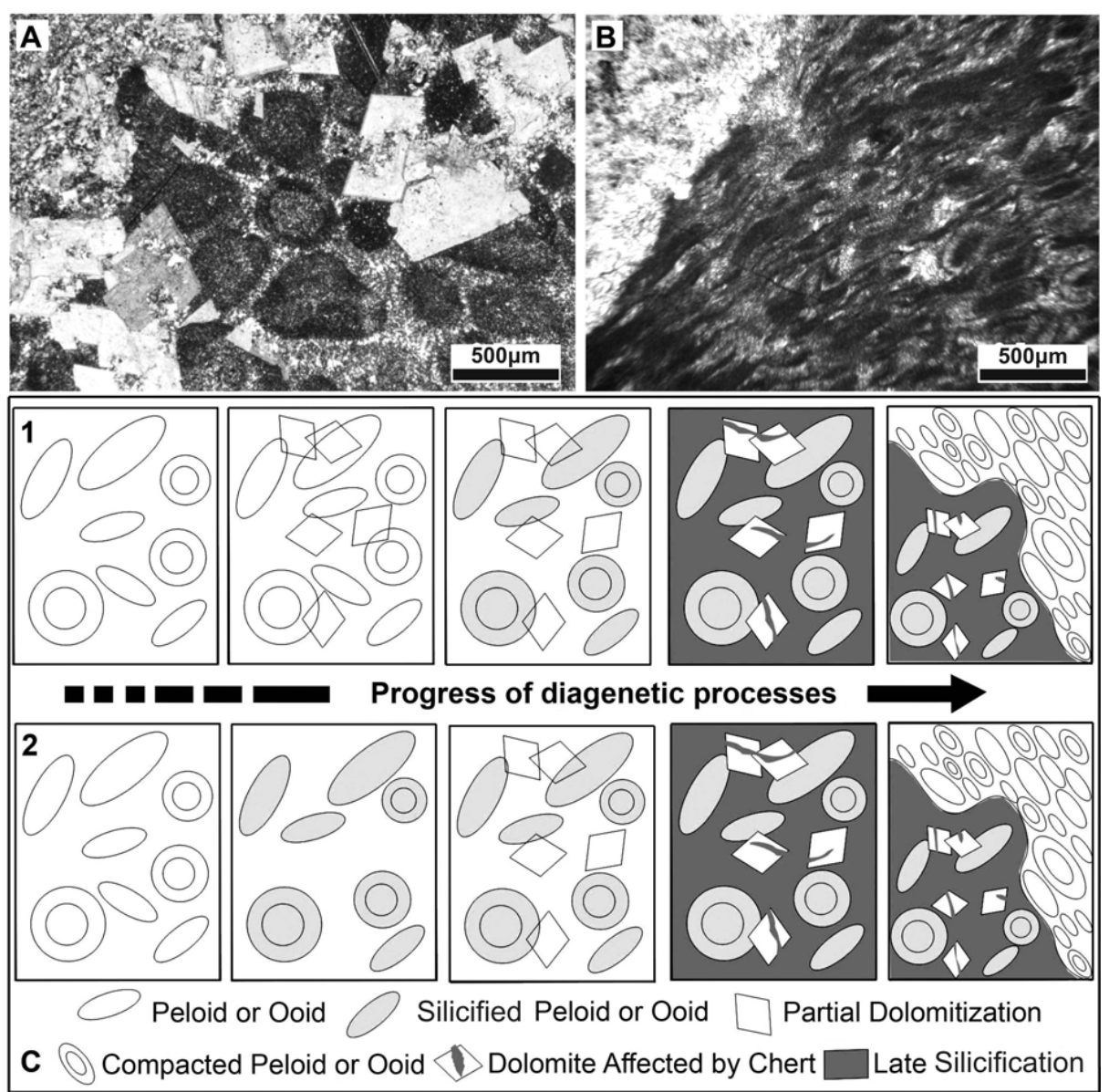

Fig. 5 - Chert and compactation. A - Thin section showing carbonate grains (peloids, ooides) totally silicified, associated with dolomite rhombs. Plane-polarized light. B - Same thin section of $\mathrm{A}$, another sector, highly compacted carbonate grains in contact with chert nodule. $\mathrm{C}-$ Schematic models of the diagenetic evolution: 1 - Formation of early dolomite followed by an early selective silicification of the carbonate grains; another pulse of chert that constitutes the cement begins to affect partially the dolomite crystals. Intense compactation of non silicified components. 2 - Early silicification of the carbonate grains, partial dolomitization; later silicification that constitutes the cement and affects the dolomite. Intense compactation of non silicified components.

of chert associated with microbial structures, it is worth mentioning that the organic matter would act by absorbing the silica in the fluids. This occurs in the case of silicification during early diagenesis, when the bacterial activity and the oxidation of the organic matter are still active (Gao and Land 1991). The micro-quartz mainly replaces carbonate grains; the mega-quartz and chalcedony are mainly pore-filling cements. The microspheres and the hexagonal quartz are generally found replacing fine-grained sediments (micrite and micrite peloids).
Dolomitization in the La Silla Formation is also related to the high permeability of the host rock (M.M. Raviolo et al., unpublished data). Its already mentioned petrographical characteristics point to a very close relationship between this process and the silicification in an early diagenetic stage. Dolomite rhombs in the contact between chert and limestone indicate a selective dolomitization during an early diagenetic stage, while silica rich fluids and the host sediments interact previous to the chert formation (Giménez-Montsant et al. 1999). Evidence of this early diagenesis is also the dolomite lami- 

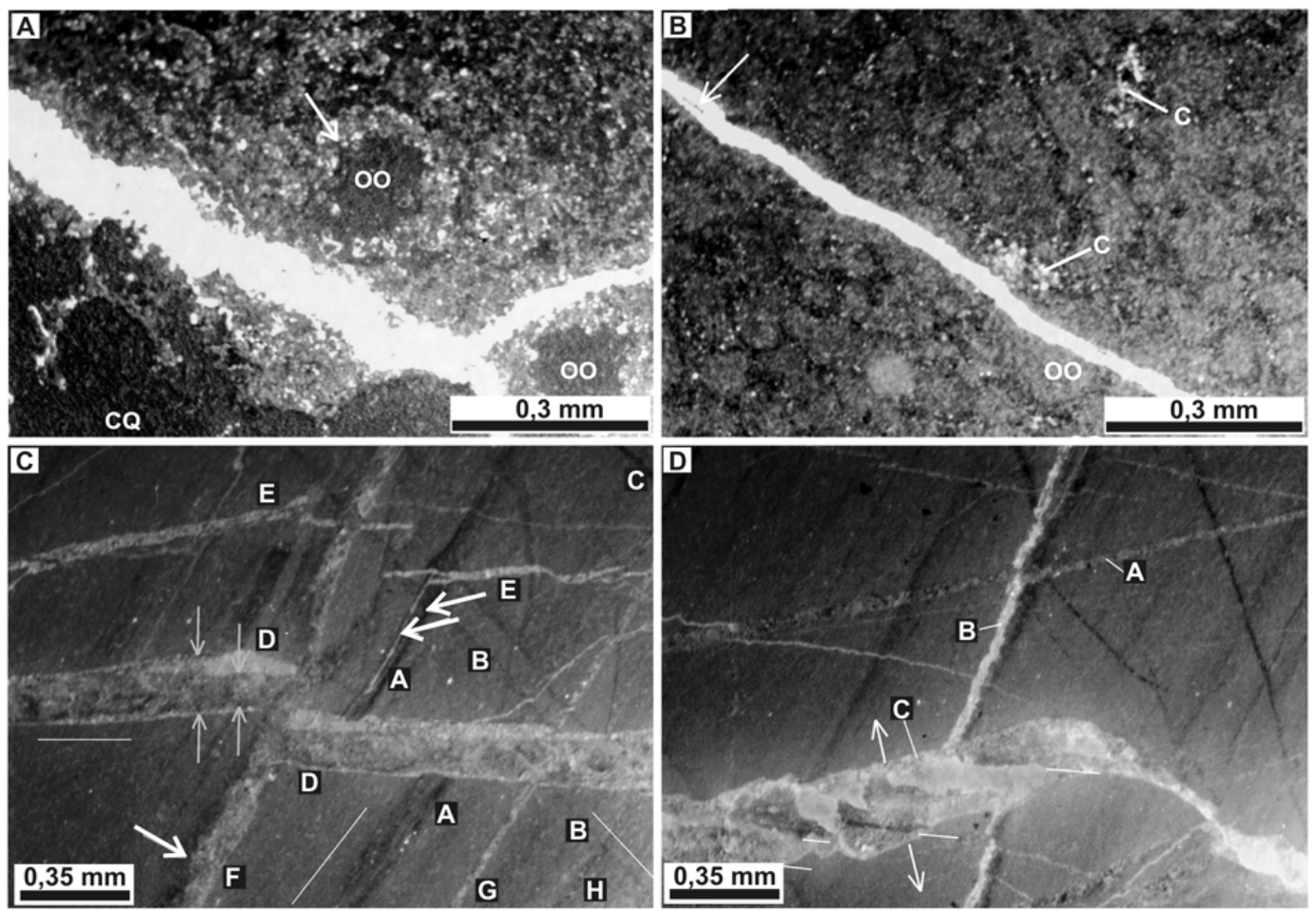

Fig. 6-Cathodoluminescence. A - Carbonate grains (OO) and cement are strongly silicified (CQ), a big fracture is observed (Mn calcite filling). The arrow points to the later replacement of the quartz cement by calcite. B Another sector of the same thin section of A. Light areas to the right are carbonate grains (OO), the quartz cement that rims the grains is more intense to the left of the picture. The fracture is Mn calcite, but it has a relict of the previous non luminescent filling (arrow). Later pulses of Mn calcite are replacing the micro-quartz (C). C-D: Different stages of fracturing in the same thin section.

nae crossing chert nodules; this indicates that the compactation and loss of water of the un-lithified carbonate took place after the silicification (Geeslin and Chafetz 1982, Gao and Land 1991). It is common to find dolomitic rhombs floating in a siliceous micro-quartz matrix; this characteristic has been considered by some authors as an evidence of dolomitization previous to silicification, and the selective replacement of the calcium carbonate of the host rock by silica (Dietrich et al. 1963, Harris and Meyers 1987). It seems easier to explain that euhedral dolomite crystals developed in a carbonate mud matrix rather than in a siliceous mass. However, there is a possibility of the process being the opposite: an early silicification of the matrix and a later replacement of this silicification by partial dolomitization. Later pulses of calcite cementation (calcitization) and dolomitization, observed with cathodoluminescence, support the last possibility.
Silicification that preserves carbonate grains from strong deformation is interpreted as an early diagenetic stage process pre-compactation (Gao and Land 1991). Figure 5C shows that, independently of what kind of process takes place before, whether it is dolomitization or silicification, both processes are previous to compactation. This early pulse of silicification is obviously previous to spar cementation and fracturing (observed with $\mathrm{CL}$ ), but later silicification pulses associated with fracturing were also observed.

\section{DISCUSSION}

There is no evidence of subaerial exposure or indications of environmental restriction associated to the chert location within the area under study, such as mud-cracks and evaporites, among others. There is no evidence of terrigenous detritic material derived from continental areas. 
No spicules (or only very few) and very scarce bioclasts were found, which generates doubts about the origin of the silica. The fact that the sediments were affected by the silicification during early diagenesis may have caused the dissolution of these components (Maliva and Siever 1989); this means that, in these carbonates, one of the silica sources may be biogenic, although there are no organisms' remains.

Gao and Land (1991), in an example similar to this study, inferred that chert could have been formed during early diagenesis in marine environments, and they propose silica enriched seawater as a source of it. Another consideration given by these authors is the fact that the nucleation of chert is favoured by the sediment porosity and permeability.

Other possible sources of silica that cannot be discarded are those connected with the participation of meteoric water that, in contact with seawater, generates a favourable model of silicification in shallow platform carbonates. There are mentions of hydrothermalism connected with fracturation in the area of eastern Precordillera, in Paleozoic rocks (Ormeño 2002), and also the volcanic influence: there are K-bentonites in neighbouring areas of the basin (eastern and central belts of the Precordillera) of Lower Ordovician age (Huff et al. 2003, Huff 2008). Later chert stages may represent periods of dissolution and reprecipitation of silica present in the rocks since early diagenesis.

According to the descriptions made in the Cathodoluminescence section, it is clear that the fluids that circulated through these rocks were varying their composition, which could generate the different types of chert.

\section{CONCLUSIONS}

Chert is an important component in the carbonates of the La Silla Formation; different types of chert were identified, described, interpreted, and located in the stratigraphic sections.

Using petrographical analyses with cathodoluminescence support, it is possible to confirm the existence of an early pulse of chert connected with porous and permeable sediments in contact with silica rich seawater. This early pulse is probably simultaneous with the dolomitization process and previous to the compactation process. A later pulse of chert associated with frac- turation is also recognized.

\section{ACKNOWLEDGMENTS}

We are grateful to the Laboratório de Catodoluminescência, Departamento de Geologia, Universidade Federal de Pernambuco (UFPE), Recife, Pernambuco, Brazil, for the cathodoluminescence analyses. We also thank J.M. Mabesoone for critics and suggestions. Comments from F.G. Aceñolaza and an anonymous reviewer also helped to improve the manuscript.

\section{RESUMO}

A Formação La Silla (Neo Cambriano-Neo Tremadociano) é formada por depósitos carbonáticos da região da Pré-Cordilheira leste, Argentina. As faciologias encontradas em tais depósitos indicam um ambiente de deposição caracterizado por uma plataforma rasa. Até o momento, nenhum estudo tratou especificamente da evolução diagenética dessas rochas. O presente estudo envolve as características e distribuição da silicificação que afeta esta formação e apresenta os diferentes estágios diagenéticos ocorridos, através de análises petrográficas (auxiliadas por catodoluminescência) e estratigráficas. Foi identificado um pulso precoce de silicificação, anterior ao processo de compactação das rochas afetadas. Esta silicificação foi favorecida pela presença de água do mar rica em sílica em contato com sedimentos porosos e permeáveis. Também foi identificado um pulso de silicificação tardia, associado a eventos de fraturamento das rochas. O conhecimento adquirido sobre as características e a distribuição da silicificação nestes depósitos carbonáticos é importante, especialmente quando se considera que a Formação La Silla, na Província de San Juan, é a formação mais minerada para a produção de calcário.

Palavras-chave: carbonatos, chert, diagênese inicial, Pré-Cordilheira Oriental, Ordoviciano Inferior.

\section{REFERENCES}

Alvárez-Marrón J, Rodríguez-Fernández R, HereDia N, Busquets P, Colombo F AND Brown D. 2006. Neogene structures overprinting Palaeozoic thrust systems in the Andean Precordillera at $30^{\circ} \mathrm{S}$ latitude. J Geol Soc London 163: 949-964.

BALdis BA AND CheBli GA. 1969. Estructura profunda del área central de la Precordillera Sanjuanina. IV Jornadas Geológicas Argentinas, Mendoza, Argentina. Asociación Geológica Argentina, Actas 1: 45-65. 
BATES RL AND JACKSON JA. 1980. Glossary of geology, $2^{\text {nd }}$ ed., Am Geol Inst, Falls Church, Va, 749 p.

BORDONARO OL. 2003a. Review of the Cambrian stratigraphy of the Argentine Precordillera. Geol Acta 1: 11-21.

Bordonaro OL. 2003b. Evolución paleoambiental y paleogeográfica de la cuenca cámbrica de la Precordillera argentina. Rev Asoc Geol Argentina 58: 329-346.

Buggisch W, Keller M and Lehnert O. 2003. Carbon isotope record of Late Cambrian to Early Ordovician carbonates of the Argentine Precordillera. Palaeogeogr palaeocl palaeoec 195: 357-373.

CAÑAS FL. 1999. Facies and sequences of the Late Cambrian. Early Ordovician carbonates of the Argentine Precordillera: A stratigraphic comparison with Laurentian platforms. Geol Soc Am Spec Pap 336: 43-62.

Dietrich R, Hobbs C And Lowry W. 1963. Dolomitization interrupted by silicification. J Sediment Petrol 33: 646-663.

GAO G AND LAND L. 1991. Nodular chert from the Arbuckle Group, Slick Hills, SW Oklahoma: a combined field, petrographic and isotopic study. Sedimentology 38 : 857-870.

GeEslin J AND Chafetz H. 1982. Ordovician Aleman ribbon cherts: an example of silicification prior to carbonate lithification. J Sediment Petrol 52: 1283-1293.

Giménez-Montsant J, Calvet F And Tucker M. 1999. Silica diagenesis in Eocene shallow-water platform carbonates, southern Pyrenees. Sedimentology 46: 969-984.

HARRIS D AND MEYERS W. 1987. Regional dolomitization of subtidal shelf carbonates: Burlington and Keokuk Formations (Mississippian), Iowa and Illinois. In: MARShALl J (Ed), Diagenesis of Sedimentary Sequences, Geol Soc Spec Publ 36: 237-258.

HuFF WD. 2008. Ordovician K-bentonites: Issues in interpreting and correlating ancient tephras. Quatern Int 178: 276-287.

Huff WD, Bergstrom S, Kolata D, Cingolani C, Krekeler M ANd Prokopenko M. 2003. Ordovician K-bentonites in the Argentine Precordillera and their relation to Laurentian volcanism. INSUGEO, Tucumán, Serie de correlación Geológica 17: 197-202.

Keller M. 1999. Argentine Precordillera. Sedimentary and plate tectonic history of a Laurentian crustal fragment in South America. Geol Soc Am Spec Pap 341: 131.

Keller M, CAÑas FL, Lehnert O And Vaccari Ne. 1994. The Upper Cambrian and Lower Ordovician of the
Precordillera (western Argentina): Some stratigraphic reconsiderations. Newsl Stratigr 31: 115-132.

Kobayashi T. 1937. The Cambro-Ordovician Shelly faunas of South America. Faculty of Science Journal, Imperial University of Tokyo, section II: Geol Mineral Geogr Seism 4: 369-522.

LAWRENCE M. 1994. Conceptual model for early diagenetic chert and dolomite, Amuri Limestone Group, northeastern South Island, New Zealand. Sedimentology 41: 3479-3498.

Maliva RG. 2001. Silicification in the Belt Supergroup (Mesoproterozoic), Glacier National Park, Montana, USA. Sedimentology 48: 887-896.

Maliva RG AND Siever R. 1989. Chertification histories of some Late Mesozoic and Middle Paleozoic platform carbonates. Sedimentology 36: 907-926.

ORMEÑO P. 2002. Evidencias de eventos hidrotermales en la Precordillera Oriental, San Juan. XV Congr Geol Argentino, El Calafate, Actas II, p. 393-397.

ORTIZ A AND ZAMBRANO JJ. 1981. La provincia geológica Precordillera Oriental. VIII Congr Geol Argentino, Actas III, p. 59-74.

Pope M. 2004. Cherty carbonate facies of the Montoya Group, southern New Mexico and western Texas and its regional correlatives: a record of Late Ordovician paleoceanography on southern Laurentia. Palaeogeogr palaeocl palaeoec 210: 367-384.

RAmos VA. 1988. The tectonics of the Central Andes; $30^{\circ}$ to $33^{\circ} \mathrm{S}$ latitude. In: Processes in Continental Lithospheric Deformation, CLARK SP, BURCHFIELD BC AND SUPPE J (Eds), Geol Soc Am Spec Pap 218: 31-54.

Ramos VA. 1999. Las provincias geológicas del territorio argentino. In: Geología Argentina, CAMinos R (Ed), Inst Geol Rec Min Serv Geol Min, Anales 29: 41-96.

Raviolo MM, Bordonaro OL and Pratt BR. 2007. Revisión estratigráfica y litofacial de la Formación La Silla (Ordovícico Inferior) en la Precordillera Oriental de San Juan, Argentina. Lat Am J Sed Basin Anal 14: 117-128.

Sial an, Peralta S, Ferreira VP, Toselli AJ, AceÑ And Pimentel MM. 2008. Upper Cambrian carbonate sequences of the Argentine Precordillera and the Steptoean C-Isotope positive excursion (SPICE). Gondwana Res 13: 437-452.

ToBin KJ. 2004. A survey of Paleozoic microbial fossils in chert. Sediment Geol 168: 7-107. 